\title{
RISC-Loading Complex Subunit TARBP2
}

National Cancer Institute

\section{Source}

National Cancer Institute. RISC-Loading Complex Subunit TARBP2. NCI Thesaurus. Code C84409.

RISC-loading complex subunit TARBP2 (366 aa, $39 \mathrm{kDa}$ ) is encoded by the human

TARBP2 gene. This protein plays a role in both HIV-1 infection and mRNA metabolism. 